\title{
ОБРАЗ РУССКОГО КУПЦА: СТЕРЕОТИПЫ И РЕАЛЬНОСТЬ
}

\author{
И. Р. Федоркова \\ Московский гуманитарный университет
}

\begin{abstract}
Аннотация: В статье на основе анализа конкретных исторических примеров и личных путевых заметок купцов реконструирован образ русского купца-международника. Охарактеризованы значимые исторические этапы, показаны исторические персоналии (Иван Калита), повлиявшие на формировании уникального образа русского купечества. Выявлены психологические (волевые, когнитивные и др.) и социально-психологические (компетентность в общении, эффективность взаимодействия) характеристики русских купцов.
\end{abstract}

Ключевые слова: русский купец, средневековый купец; история России; история купечества

\section{THE IMAGE OF THE RUSSIAN MERCHANT: STEREOTYPES AND REALITY}

\author{
I. R. Fedorkova \\ Moscow University for the Humanities
}

\begin{abstract}
The article is based on an analysis of specific historical examples and personal travel notes of merchants and reconstructs the image of the Russian international merchant. The relevant historical periods are described; classic characters (Ivan Kalita), who influenced the formation of unique identity of Russian merchants, are depicted. The author reveals the psychological (volitional, cognitive, etc.) and psychosocial (competence in communication, effectiveness of interaction) characteristics of Russian merchants.
\end{abstract}

Keywords: Russian merchant; medieval merchant; history of Russia; history of merchants

В обыденном сознании современных россиян существует стереотипный образ купца - «толстосума и толстопуза», скупого и неповоротливого, жадного до личной наживы, человека неинтеллигентного и необразованного, для которого высокие идеалы служения Отечеству, стремление к познанию и личная отвага - явления абсолютно чуждые. Вместе с тем вся история становления отечественного купечества свидетельствует об ином: купцы являлись одной из самых активных групп русского общества, способствовавших не только экономическому развитию страны, но и выполняю-

\footnotetext{
* Работа выполнена при поддержке гранта РФФИ № 18-013-01075 «История становления предпринимательства в России».
} 
Научные труды Московского гуманитарного университета 2019 № 5

щих ряд неспецифических для данного сословия функций: они выступали в роли дипломатов и разведчиков, паломников и благотворителей, проводников и фельдъегерей, писателей и просветителей, землепроходцев-исследователей.

Русский купец периода Киевской Руси с IX по XI вв. - купец-воин (Федоркова, 2018). В этот период купцы входили в состав дружины и были сподвижниками князя при решении любых вопросов. Например, Владимир Великий (Х в.) отправлял купцов с посольскими поручениями в разные страны и города: Иерусалим, Рим, Египет (Карпов, 2004; Преображенский, Перхавко, 1997).

Политическая раздробленность, наступившая после смерти Ярослава Мудрого (XI в.), междоусобицы князей и впоследствии монголо-татарское нашествие несколько притормозили развитие торговли в период с XI по XIV вв. Кроме того, именно в этот период (с XI в.) происходит выделении купечества из состава княжеской дружины в самостоятельную профессиональную группу (Перхавко, 2012). Купцы, по сути, удалились из состава референтной группы князя, становясь его богатыми слугами, а не соратниками ${ }^{1}$. Таким образом в названный период несколько снизилась общая активность купечества, и одновременно поколебалась их социальная позиция.

Профессиональная деятельность купцов была сопряжена с риском и преодолением большого числа трудностей: помимо дорожных сложностей, связанных с длительностью пути в разных погодно-климатических условиях (степь, пустыни, болота, горные дороги), существовала большая вероятность попасть в опасную ситуацию: ограбление, плен, продажа в рабство 2 .

\footnotetext{
${ }^{1}$ Вероятно, с этого времени в высших слоях появляется тенденция в оценке купцов как «худородных», сохранившаяся вплоть до XIX века, так как источником пополнения купечества являлись активные представители всех слоев населения, в том числе из простонародья; критерием отбора являлись личные способности, а не происхождение.

${ }^{2}$ Например, в 1489 г. на нижнем течении Днепра 120 русских купцов были ограблены крымскими татарами. В 1500 г. 60 купцов (москвичи, тверичи, можайцы, ярославцы, новгородцы), отправившихся в торговую экспедицию в Кафу и Азов, попали в беду: 22 из них - умерли (причина не указана), 4 - были проданы в рабство, 2 - были убиты, а остальные - ограблены на обратном пути (Осипов, 1956). Новгородские летописцы зафиксировали следующие события: в 1130 г. семь ладей купцов, плывших с товарами со шведского острова Готланд погибли в море; в 1142 г. на купеческие суда новгородцев пиратски напали шведы (Преображенский, Перхавко, 1997). Тверской купец Афанасий Никитин неоднократно оказывался в сложных ситуациях за период своего шестилетнего путешествия в Индию (Хождение за три моря ... , 1958). Казанский купец Василий Гагара, возвращаясь из Иерусалима, был арестован в Польше и просидел под арестом 14 недель (Житие и хождение ... , 1891). Московский купец Василий Позняков вместе с Александрийским патриархом находился в Синайской пустыне под угрозой нападения арабов (Послание царя ..., , 1884).
} 
Купцы, отправлявшиеся в экспедиции, осознавали риск, но от ведения дел не отказывались, демонстрируя широкий спектр волевых свойств: смелость, решительность, целеустремленность, способность к действиям в неопределенных, порой опасных обстоятельствах.

Купечество активизировалось и стало существенно укреплять свои позиции с XIV в. в период Московского княжества при Иване Калите (13251340). Появившийся новый тип «князя-хозяина» в отличие от «князя-воина» определил особую роль купечества в социальной структуре общества. Князь-хозяин делал ставку не столько на ведение войн с целью расширения территорий, сколько на обустройство собственных владений: занимался строительством городов, развитием ремесел и торговли. Иван Калита сделал ставку на купцов, оценив их смекалку, предприимчивость, деловую расчетливость и готовность к риску; они стали его главными помощниками. Между князем и купцами были установлены надежные партнерские отношения. В случае необходимости купцы кредитовали князя, а Иван Даниилович, в свою очередь, проводил выгодную для них финансовую политику. Он приглашал их в свой терем (тем самым повышая статус купцов) для ведения деловых переговоров и совершения торговых сделок; никогда не забирал товар бесплатно, покупал его по сниженной цене, умело торгуясь. Такое уважительное отношение к купцам (позиция «рядом») было характерно не для всех князей. Например, высокомерное отношение к новгородским купцам тверского князя (позиция «сверху»), породило избегание контактов с ним и выбор в пользу московского князя (Борисов, 1995). Купцы ценили Ивана Калиту: выполняли его личные просьбы и официальные поручения не только экономического характера; привозили князю разведданные из разных земель; новгородские купцы ездили в Орду просить у хана ярлык на великое княжение для московского князя (Шишов, 2006).

В период правления Ивана Калиты за купцами надежно закрепились роли «дипломатов» и «разведчиков». Они продолжали выполнять официальные и неофициальные поручения государственно-политического характера и в последующие годы.

Князь Дмитрий Донской (1359-1389), отправляясь в 1380 г. на Куликовское поле, взял с собой 10 купцов-сурожан ${ }^{1}$ - Тимофея Весякова, Дементия Саларева, Ивана Шиха, Василия Капицу и др. (Сказания ... , 1982). С одной стороны, они служили в качестве проводников для княжеской дружины, так как являлись лучшими знатоками дорог; с другой стороны, должны были

${ }^{1}$ Купцы - сурожане - богатые московские купцы (гости) XIV-XV вв., специализировавшиеся на торговле с Византией, итальянскими городами, а затем - с Турцией через порт Сурож (совр. Судак) в Крыму. 
Научные труды Московского гуманитарного университета 2019 № 5

оперативно известить об итогах битвы международное сообщество. Кроме того, князь намеревался использовать купцов в качестве дипломатов и переводчиков, так как знание иностранных языков и менталитета разных народов могли пригодиться при проведении переговоров с иноземцами-наемниками, входившими в состав армии Мамая (Лощиц, 2010).

Купцы выступали и в роли проводников, попутчиков и защитников для отправляющихся в паломнические поездки священников и монахов. Так, инок Зосима (XV в.) пошел в Палестину из Киева «с купцы и вельможами с великими» (Данилов,1962: 28).

В царствование Федора Иоанновича по делу учреждения патриаршества на Руси в Москву приезжал Антиохийский патриарх Иоаким. На обратном пути его сопровождали подьячий Михаил Огарков и купцы Федор Андреев и Иван Дезжемандуро. Кроме выполнения основной миссии, компаньоны должны были передать Царьградскому патриарху 375 рублей и письмо, в котором царь просил выдать посланцу проезжую грамоту, сообщив о дополнительных целях поездки М. Огаркова (выкупить из турецкого плена сына) (Лопарев, 1889). В данной экспедиции купцы выполняли сразу несколько ролей: проводников, охранников, послов и, возможно, переговорщиков по вопросу выкупа сына подьячего.

Важной являлась информационная функция купцов: их рассказы служили источниками для летописцев. Так, Л. Е. Морозова считает, что автор Лаврентьевской летописи именно от купцов узнал об обстоятельствах крещения князя Владимира в Херсонесе (Морозова, 2017). Купцы участвовали в формировании общественного мнения по разным вопросам. В своих поучениях Владимир Мономах говорил детям о том, что купцы и послы могут «прославить человека по всем землям или добрым, или злым» (Поучение, 1996: 63).

Купцы-просветители привозили на Русь сведения о разных странах и народах. C XII в. у русских путешественников сложилась традиция составлять путевые заметки - «Хождения». Тексты хождений включались в состав летописных сводов и использовались как самостоятельные произведения. Они многократно переписывались и были популярны среди всех слоев населения: от князей до посадских людей. Путевые заметки с одной стороны выступали в роли путеводителей и имели практическую значимость для соотечественников, отправлявшихся за границу; с другой стороны носили обще-просветительский характер.

C XII по XIV вв. - экспедиции в основном носили паломнический характер, авторами записок являлось духовенство. Первое «Хождение» составил игумен Даниил («Хожение» ... , 2007), описав в XII в. свое путешествие в Иерусалим, и утвердив образец для подготовки путевых заметок: описывать 
только то, что сам воспринимал; представлять материал в виде коротких рассказов; использовать простой язык, понятный широкому кругу читателей.

C XIV в. появляется новый тип путешественников, нацеленных помимо паломничества на реализацию практических задач государственно-политического и торгового характера. Обнаружены тексты купеческих «Хождений»: периода правления Ивана III (XV в.) - записки купцов Василия (фамилия неизвестна) (Хожение гостя Василия ... , 1984) и Афанасия Никитина (XV в.) (Хождение за три моря ... , 1958); периода правления Ивана Грозного и Федора Ивановича (XVI в.) - Василия Позднякова (Послание царя ... , 1884) и Трифона Коробейникова (Второе хождение..., 1887; Отчет дьяка ... , 1889; Хождение купца Трифона ... , 1889); периода правления Михаила Федоровича (XVII в.) - Федота Котова (Хождение купца Федота ... , 1958) и Василия Гагары (Житие и хождение ... , 1891).

Разные цели поездок определили особенности записок. Поездки купцов Василия (1465-1466 гг.) и Василия Гагары (1634-1637 гг.) относились к разряду частных поездок и предположительно были связаны с выполнением неофициальных государственных поручений. Василий, вероятно, отправился в паломничество, так как значительная часть записок связана с описанием святых мест, к которым пришел и поклонился купец. Кроме того, Василий описывал города с акцентом на стратегически значимые объекты (крепости, укрепления, стены, ворота, улицы, бойницы) и наличие христиан: «христиан мало», «христиан много», «христиан мало, а боле сарацины» (Хождение гостя Василия ... , 1984: 177). Выступало ли внимание к данным вопросам личной инициативой Василия или это было прямым заданием царя? Вполне вероятно, что верен второй вариант. К моменту поездки купца Василия (1465 г.) минуло всего 12 лет с момента падения Византии (1453 г.), в результате чего Россия осталась единственным православным государством в мире. В это время усилились попытки Папы Римского насадить католичество на Руси. В этот же период появилась теория «Москва - Третий Рим», обозначившая особую миссию России в сохранении православной веры до второго пришествия Христа (Кириллов, 1996). В связи с этим Ивану III, формирующему политику в новых условиях, необходимо было знать о местах сосредоточения христиан.

Наряду с описанием храмов, купец Василий называл имена священников и тяготение прихода к той или иной патриархии (иерусалимской, антиохийской и др. $)^{1}$. Впоследствии купцы отправлялись по указу царей в Иеру-

${ }^{1}$ «ррад Казья Самсона сильнаго град, стоит у Белаго моря; церковь в нем Пречистая, а митрополит в нем Михаил, а христиан в нем много, а тянет к патриарху Иерусалимскому» (Хожение гостя Василия ... , 1984: 173). 
Научные труды Московского гуманитарного университета 2019 № 5

салим и Константинополь для оказания финансовой помощи христианам с готовыми списками приходов и именами священников. Вероятно, при помощи таких же купцов, как Василий, эти списки и формировались.

Казанский купец Василий Гагара (XVII в.) подробно описал причину своей поездки на Святую Землю. Трагические события личной жизни (смерть супруги, неудачи в торговле) заставили его задуматься о неправедном характере собственной разгульной жизни и побудили осуществить покаяние на Святой земле (Житие и хождение ... , 1891). Вместе с тем, на обратном пути купец уделял внимание сбору сведений политического характера: о взаимоотношении Крыма с Османской империей, об отношении Турции к Москве, о положении княжеств на Дунае. Возможно, такая заинтересованность купца отчасти сыграла роль в истории его 14-недельного ареста на территории Польши.

Князья и цари, выписывая охранные грамоты купцам, могли одновременно давать им неофициальные поручения разведывательного характера, скорее всего, именно в посткризисные периоды: поездка купца Василия состоялась после падения Византии, а поездка Василия Гагары после завершения Смутного времени.

Поездки Василия Позднякова (1558-1561 гг.), Трифона Коробейникова (1582-1584 гг.; 1593-1594 гг.) и Федота Котова (1623-1624 гг.) относились к разряду официальных дипломатических экспедиций. Если в поездках двух Василиев личный, торговый характер мы не можем отрицать ${ }^{1}$, то в поездках В. Познякова и Т. Коробейникова однозначно доминировали государственные интересы над личными (в том числе торговыми): они доставляли милостыню православным восточным церквям. Поводом для снаряжения экспедиций могли быть прямые просьбы о помощи восточных патриархов или инициатива русских царей в связи с рождением или смертью членов их семьи. Финансовая поддержка русских царей способствовала тому, что многие святые места в тот период оставались во владении православных христиан.

В 1558 г. царь Иван Грозный отправил посольство во главе с новгородским архилдиаконом Геннадием и смоленским купцом Василием Позняковым в ответ на просьбу Александрийского патриарха о выделении милостыни на ремонт Синайского монастыря (Послание царя ... , 1884). Архидиакон Геннадий умер в дороге и купец Василий Позняков взял руководство экспедицией на себя, продемонстрировав способность к принятию решений и принятию ответственности за дело и других людей на себя.

\footnotetext{
${ }^{1}$ В некоторых исследованиях делается вывод о доминировании торгового характера поездки купца Василия Гагары (Решетова, 2007).
} 
Александрийский патриарх Иоаким ${ }^{1}$, к моменту приезда посольства был серьезно болен, но узнав о приезде русских, вышел к купцам и долго с ними беседовал, попросив сесть рядом с собой, и в знак особого доверия держал Василия за руки. Патриарх возлагал на русского царя особые надежды и не стеснялся обсуждать свои мысли и чувства с посланниками. Судя по повествованию Познякова, беседа была длительная, носила доверительный, неформальный характер. В частности, патриарх рассказал о произошедшем чуде, о том, как ему по приказу султана довелось выпить приготовленный яд и как, с верой приступив и осенив крестным знамением чашу, он выпил содержимое и остался невредим. Врач, готовивший зелье, по требованию султана вылпил волду из этой же чаши и умер (Послание царя ... , 1884: 4-8). Затем патриарх вместе с купцами отправился в длительное (больше месяца) паломничество по святым местам. Святитель Иоаким проводил богослужения в разных храмах, а в качестве почетных гостей, фактически друзей с ним рядом находились русские купцы. Они вместе преодолели тяжелый путь по пустыни, когда, по словам Василия, 3 дня не видели ни леса, ни травы, ни воды, а только песок и камни. Вместе осуществили сложный подъем на Синай, вместе преодолели опасности обратного пути.

На протяжении всего путешествия Василий Позняков общался с иерархами православных зарубежных церквей фактически на равных: они вместе путешествовали, много беседовали и даже плакали вместе. Эти факты свидетельствуют, во-первых, о достаточно высоком статусе русских купцов-международников периода средневековья; во-вторых, о высоком уровне компетентности в общении русских предпринимателей. Последний вывод доказывается большим количеством примеров из личных историй других купцов.

Афанасий Никитин оказался в сложной ситуации в Джунире. Хан отобрал у него коня и назначил 4 дня для принятия решения о переходе в ислам. Хлопотать за Никитина отправился, прибывший в Индию «в канун Спасова дня» хоросанец - ходжа ${ }^{2}$ Мухаммед. «И он ездил к хану в город и уговорил его, чтобы меня в веру не обращали: он же и жеребца моего у него взял» (Хождение за три моря ... ,1958: 75). Возможно, уже в первые дни пребывания в Индии Афанасий отыскал знакомых восточных купцов. Только уважительное отношение лично к Афанасию могло стимулировать потомка

\footnotetext{
${ }^{1}$ Святитель Иоаким (Пани) был избран патриархом Александрийским в 1487 г., скончался - в 1567 г., в возрасте 119 лет. С его именем связаны многие чудеса. Причислен к лику святых. Решением Священного Синода в 2003 г., его память была внесена в диптих святых Русской Православной Церкви.

${ }^{2}$ Ходжа - человек, ведущий своё происхождение от арабских миссионеров ислама.
} 
арабских миссионеров ислама отправиться в сложный путь в Джунир (по узкой тропе высоко в горы) хлопотать за иноверца. Корыстные мотивы исключались в силу ненадежного статуса Афанасия в Индии: одинокий христианин в чужой стране, у которого единственным богатством был конь и, судя по тексту, ходжа коня Афанасию отдал, хоть вполне мог оставить его в оплату за свою услугу или даже не сообщать о том, что хан его отдал. Такое поведение ходжи можно объяснить тем, что среди восточных купцов Афанасий пользовался уважением как честный и надежный партнер, и как добрый, отзывчивый человек, возможно, не раз помогавший лично ходже Мухаммеду.

Компетентность в общении Афанасия Никитина подтверждается еще одним примером. Индусы, которые очень настороженно относились к чужестранцам, даже не принимали пищу в их присутствии, согласились взять Никитина в святое для них место - Парвату, что свидетельствует о высокой степени доверия индусов по отношению к Никитину. Афанасий писал, что «они не стали от меня таиться ни в чем, ни в еде, ни в торговле, ни в молитве, ни в иных вещах; жен своих также не скрывали» (Хождение за три моря ... , 1958: 78).

Трифон Коробейников также был компетентным в общении человеком, он знал греческий язык, активно общался с греками; дважды был на Святой Земле: в 1582 г. под руководством купца Ивана Матвеевича Мишенина (Хождение купца Трифона ... , 1889), а в 1593 г. уже в должности дьяка сам возглавлял посольство: тогда Трифон вез милостыню для раздачи восточным христианам (Второе хождение ... , 1887). Всего царем было выделено 5534 золотых угорских и меха (Отчет дьяка ... , 1889). Средства выделялись отдельно патриархам, митрополитам, архиепископам, монастырям, приходским храмам и другим категориям нуждающихся в соответствии со списком-сметой, подготовленным заранее в Москве. Со времени последнего посольства данные могли измениться, поэтому часто приходилось ориентироваться на месте, принимая самостоятельные решения. Например, одной церкви угрожало закрытие, поэтому на откуп от султана было выделено больше средств, чем было запланировано изначально. Иногда возникали ситуации, когда в монастырях, среди насельников не было указанного в списке количества человек, в этом случае излишки отдавались другим нуждающимся, например, «у приходных церквей стары и увечны 32 человекам 32 золотых» (Отчет дьяка ... , 1889: 88). Были даны незапланированная милостыня греческой вдове Ласкарине, которая хотела выдать замуж свою дочь, а денег на приданое не было, «да нищему одному человеку 3 алтына 2 денги» (там же: 89). На обратном пути, после окончания основной мис- 
сии, посольство продолжило жертвовать средства на нужды православных в Литве и Валахии, вполне возможно, что Трифон Коробейников тратил на это не только казенные, но и собственные средства.

О милосердии, искренней благотворительности русских купцов мы узнаем не от них самих, что служит дополнительным свидетельством их христианской жизненной позиции. Например, из письма александрийского патриарха Герасима царю Михаилу Федоровичу мы узнаем, что Василий Гагара выкупил из плена «москвитянина Иеремию», приложил к этому немало усилий и имел желание освободить и других людей, но не получилось по независящим от него причинам (Житие ... , 1891: 89), но в повествовании самого Василия Гагары об этой ситуации ничего не сказано.

Анализ путевых заметок позволяет сделать вывод о том, что при подготовке текстов у купцов доминировала ориентация на государственно-политическую пользу и общественные интересы. Торговый характер поездок практически у всех купцов оставался за пределами текста (только Афанасий Никитин и Федот Котов более подробно останавливались на описании торговли), возможно, утилитарные, практические вопросы, которые они решали по ходу путешествия, считали не нужным заносить в тексты, предназначенные для всеобщей пользы. Купеческое авторство записок угадывается по косвенным фактам, на которые они обращали внимание: указание местонахождения торговых и ремесленных центров, постоялых дворов, купеческих подворий, лавок, ярмарок.

Купца Василия заинтересовал город Воргоун как место соледобычи, так как там «соль копают, как лед чиста» (Послание царя ... , 1884: 170). Федот Котов вблизи Астрахани также заметил места соледобычи: Кобыльи озера, но соль там была не высокого качества - красная; и Мачеговское озеро, где соль «белая и хорошая» (Хождение купца Федота ... , 1958: 67). Купцы не могли обойти вниманием данные профессионально-значимые факты, так как соль являлась с древнейших времен не только важным международным товаром, но и выступала в качестве товарных денег (Федоркова, 2017).

Несмотря на то, что поездка купца Василия Познякова изначально носила не торговый характер, от профессионального глаза купца не ускользнули, увиденные в Раифе индийские купцы и их товар - буйволы с огромными рогами. Василий описывает также стоимость различных услуг. Например, за передвижение на верблюдах на вершину Синайской горы они заплатили по золотому, а за проход христиан в Храм Гроба Господня турки взымали плату по 4 золотых с человека (Послание царя ... ,1884).

Одним из важных мотивов путешествия Афанасия Никитина являлась разведка индийского рынка с целью установления торговых отношений 
между Индией и Русью. Афанасий дает профессиональную аналитическую оценку ситуации торговли в Индии и дважды в тексте делает заключение о том, что торговли для русских здесь нет: «На Русскую землю товара нет» (Хождение купца Федота ..., , 1958: 76).

Посольство купца Федота Котова (XVII в.) было отправлено в Персию с восемью его товарищами по указу царя Михаила Федоровича и патриарха Филарета в 1623 г. в большей степени для решения торговых вопросов. Торговля с Персией к XVII в. имела большое значение для России. В Москве находился персидский гостиный двор с лавками, персы ввозили шелк и предметы роскоши. Драгоценные камни, золотые и серебряные украшения, в первую очередь, закупала казна. Несмотря на настороженное отношение к России из-за Грузии, которая официально присоединилась к России в 1636 г., Персия, отрезанная Турцией от европейского рынка, была не менее заинтересована в развитии торговли с Россией. В Персию вывозились меха, кость, моржовые клыки, юфть, пенька, лен, хлеб (Соловьев, 2007). Купец Федот Котов в своих записках заостряет особое внимание на путях, где грабят купцов, предостерегает соотечественников. Описывает центры ремесел и торговли, местоположение рынков, караван-сараев, купеческих поселений: в Астрахани - дворы русских, бухарских и персидских купцов; в Шемахе лезгинские, гилянские, бухарские караван-сараи (Хождение купца Федота ..., 1958).

В путевых заметках Федота Котова в зоне его внимания находились не только торговые вопросы, его интересовала политика, история, этнография, география. При написании заметок купец часто использовал слова «говорят», «рассказывают», т. е. для получения информации он применял не только метод наблюдения, но и опроса, выступая в роли любознательного журналиста-исследователя.

В его работе доминирует исторический аспект ${ }^{1}$. Город Исфахан ${ }^{2}$ опи-

\footnotetext{
${ }^{1}$ Федот сообщает, например, о том, что каменные здания бывшей столицы Золотой Орды ломают и возят в Астрахань для разных нужд. Рассказывая о Багдаде упоминает историю города до захвате его в 1623 г.; говорит о городах, захваченных турками, но впоследствии отнятых персидским шахом. Купец повествует и о городах России: какие народы проживают в той или иной местности, кому подчиняются (московскому царю или «никому»). Благодаря Федоту мы узнаем где находились посты стрельцов, которые ловили разбойников; и о том, что в Царицыне скот пасли в черте города, опасаясь нападения татар; а также о том, что на пути от Саратова до Камышенки существовал острожек, в котором с осени до весны находились 500-700 стрельцов; уезжавшие с осенним астраханским товаром и сжигавшие острожек.

${ }^{2}$ Исфахан, город в центральной части Персии; был объявлен столицей при Аббасе I, т. е. незадолго до приезда Котова в Персию.
} 
сан особенно тщательно. Описывая города, дворцы, не забывал охарактеризовать их как крепости («хорошая», «плохая»). «На площади, напротив шахских ворот, лежат медные и железные пушки, среди них есть и большие, но лежат они в беспорядке, без станков и без колод, а некоторые забиты песком и землею» (Хождение купца Федота ... , 1958: 78). Обращает на себя внимание акцент на описании стратегических объектов у Федота Котова (XVII в.), как ранее у купца Василия (XIV в.), что приводит к выводу о знакомстве купцов с работами своих коллег удаленных исторических периодов и о традиционном характере выполняемых ими поручений.

Кроме того, купцы, вероятно, были знакомы с произведением игумена Даниила, и (или) с греческими проскинитариями ${ }^{1}$, так как справочная информация в хождениях купцов разных веков представлена практически в едином стиле. Общей характеристикой всех хождений является наличие формально-справочной информации: описание местоположения городов, расстояний между ними, время в пути, описание географических объектов, особенностей дороги и характера передвижения (по морю, по суше, через горы, конными, пешими, на верблюдах и т. д.).

Каждое купеческое «Хождение» имеет свои особенности, связанные с целями предпринятых путешествий, а также личностными чертами и интересами самих купцов. Например, путевые заметки Василия Познякова (XVI в.) являются ценным источником по изучению истории Египта и Иерусалима XVI века (Послание царя..., 1884). Записки Федота Котова дополнительно выступают в роли самоучителя (он приводит турецкий, персидский, грузинский счет до 100, а также армянскую азбуку) (Хождение купца Федота.., 1958). Записки Афанасия Никитина (XV в.) - землепроходца, первого русского человека, добравшегося до Индии, дают целостное представление о разных сторонах жизни Индии: от бытовых до политических (Хождение за три моря ... ,1958).

Хождение московского купца Трифона Коробейникова (Хождение купца Трифона ... , 1889), пользовалось широкой популярностью, помещалось в хронографах, между житиями святых и поучениями Иоанна Златоуста и насчитывало свыше двухсот списков и около полусотни печатных изданий, причем в виде лубочной книжки с ориентацией на малограмотные слои населения записки издавались в начале XX веке (1913 г.) (Данилов, 1962: 21) и продолжают переиздаваться в наше время (Путешествие московских купцов ..., 1994, 1999). В 1868 г. даже рассматривался вопрос об использовании книги Трифона Коробейникова в учебных программах сельских народных

\footnotetext{
${ }^{1}$ Проскинитарий - греческий путеводитель для паломников (от греч. «поклонник», «паломник»).
} 
Научные труды Московского гуманитарного университета 2019 № 5

школ. Постановили, что «знакомить детей с этой книгой очень полезно для развития в них религиозного чувства вообще и в частности чувства благоговения к священным местам и предметам» (Лопарев, 1889: XV). Кроме того, критики отмечали, что произведение «читается детьми легко и охотно» (там же) ${ }^{1}$.

Только в XIX веке выяснилось, что в основе записок Трифона Коробейникова лежит более раннее произведение - рукопись купца Василия Познякова (Послание царя ... , 1884). Эта рукопись принадлежала князьям Кропоткиным, бережно передававшим ее из поколения в поколение. Князь Василий Васильевич в 1675 г. собственноручно сделал список путевых заметок купца Василия Познякова, а князь Иван Михайлович в 1733 г. поставил собственную подпись, еще раз подтвердив факт принадлежности рукописи семье Кропоткиных. Это лишний раз свидетельствует о значимости для русской истории и культуры этого произведения, написанного купцом.

Существование хождений свидетельствует о высоком уровне образованности русских купцов-международников. Менее образованным из всех купцов был, вероятно, Василий Гагара, в заметках которого практически отсутствует цитирование Священного писания, слог близок к простонародному, отличается большей непосредственностью, порой наивностью изложения.

Купцы владели иностранными языками. Свободное общение с хоросанцами, употребление иностранных слов в записках, а также последняя молитва к Богу, написанная на иностранном языке, свидетельствует о владении Афанасием Никитиным восточными языками. Н. А. Сандыбаева считает, что он хорошо владел персидской и тюркской разговорной речью, в отличие от других наших путешественников, в записках которых преобладали греческие слова (Сандыбаева, 1981). Лингвисты перевели текст молитвы, написанной Никитиным, и пришли к выводу о том, что в ней присутствует комбинация татарского и староузбекского языков с примесью хорезмийских форм и отдельных арабских и персидских фраз. Ученые предположили, что еще до путешествия в Индию Афанасий Никитин мог изучить тюркский смешанный язык, часто бывая по торговым делам в городах Поволжья, где было много хорезмийцев, и этот язык был разговорным в среде купцов. Либо он изучил язык, уже будучи в Иране и Индии, так как общался в основном с индийскими мусульманами, в среде которых употреблялся персидский язык. Арабских слов в его записках также обнаружено много - около 280 (Петрушевский, 1958).

Особенностью русских путевых заметок является то, что наряду с фор-

\footnotetext{
${ }^{1}$ Произведение другого купца - Афанасия Никитина - «Хождение за три моря» в современных российских школах XXI века учителя рекомендуют для летнего чтения.
} 
мальной справочной информацией, русские путешественники добавляли в повествования собственные впечатления, превратив тем самым путевые заметки в произведения художественной литературы. Д. С. Лихачев отмечал, что «литература и деловая письменность борются в этих отчетах, попеременно одолевая друг друга» (Лихачев, 2008: 323).

Купцы описывали некоторые необычные для них события и явления, которые вызвали интерес и показали нам их как людей любознательных и наблюдательных ${ }^{1}$.

${ }^{1}$ Купец Василий рассказывал об интересной системе водопроводов, водяных мельницах, финиковых деревьях, о том, что в некоторых городах на конях верхом не ездят (Хождение гостя Василия ... , 1984). Трифон Коробейников повествует о турецких дервишах, которых сравнивал с русскими монахами, но только турки «усы, брады и брови бреют» (Второе хождение ... , 1887: 14). Василий Гагара рассказал о сахарном тростнике; описал египетские инкубаторы, в которых одноразово закладывалось до шести тысяч яиц; повествует о египетском «водяном звере» - «коркодиле», у которого голова как у лягушки, глаза как у человека, а хвост «сомовей» и что этот зверь, настигая человека, пожирает его, а ловят его «арапы великой мудростию и привозят временем во град паше» (Житие ..., 1891: 30). Подробное описание экипировки воинов и боевых слонов, пышные выходы знати наряду с описанием картин из жизни простонародья характерно для записок Афанасия Никитина. Он, например, замечает, что коней в Индии кормят горохом и варят для них рис с сахаром (на Руси такого не увидеть), а рано утром дают им еще и рисовые лепешки. Обезьяны вызвали интерес у купца, к описанию их жизни он дважды обращается по ходу повествования. Купец пишет о том, что обезьяны могу нападать на города и «побивать» людей, что у них рождается много детей, но некоторых они бросают и тогда местное население их подбирает и продает или учит лицедействовать; ночью люди по дорогам ездить не смеют, опасаясь нападения обезьян (Хождение за три моря ... , 1958).

Федот Котов описывает много персидских традиций и обычаев. Например, в Казвине «на площади устраивают различные зрелища: борются борцы, дают кукольные представления, носят в руках и выпускают живых змей, предсказывают судьбу по книгам, здесь же продают много всякого харчу и овощей. Детей обучают грамоте тоже на этой площади. Воровства здесь нет. В Казвине содержатся шахские звери - слоны и тигры» (Хождение купца Федота ... , 1958: 76). Вероятно, тигр произвел особое впечатление на купца, так как через несколько страниц он возвращается к этой теме и дает его описание. «Есть в Казвине зверь - тигр, он величиною больше льва, шерсть у него цвета глины, низкая, поперек идут черные полосы. Губы, как у кота, и повадки кошачьи, а сам пузатый, ноги короткие, тело длинное, голос сильный и страшный, когти, как у льва» (Хождение купца Федота ... , 1958: 92). Федот Котов рассказывает о фонтане («В середине бассейна поставлена медная труба, из которой бьет вверх из-под земли вода выше роста человека» (Хождение купца Федота ... , 1958: 82), и о том, что «сена нет во всей шахской земле, вместо него продают только скрученную в трубки траву» (там же: 81). Очень удивил купца факт, что на стене мечети он увидел христианские иконы, привезенные из Грузии: «Рождество Христово» и «Вход в Иерусалим», а с другой стороны - «Преображение Господне» и «Богоявление» с русской надписью, и писаны они красками, размером в пядь. Эти иконы повешены высоко, выше роста человека, их едва можно достать рукою» (Хождение купца Федота ... , 1958: 83). Котов также рассказывает об интересном факте проявления милосердия к 
Научные труды Московского гуманитарного университета 2019 № 5

Можно отметить сдержанность в проявлении эмоций при написании заметок, даже сложные, критические ситуации описывали в простой повествовательной форме, что свидетельствует о высоком уровне самообладания, критичности мышления и способности взглянуть на ситуацию со стороны (отсутствие эгоцентризма). Эмоциональные реакции проявлялись крайне редко и в большинстве случаев были связаны с переживанием религиозных чувств. Афанасий Никитин дает эмоциональные реакции на обстоятельства невозможности ведения на чужбине полноценной христианской жизни. «Я же, рабище Божий Афанасий настрадался по вере: уже прошли четыре великих заговенья и 4 Великих дня, а я, грешный, не знаю когда Великий День или заговенье, не знаю, когда Рождество Христово и другие праздники, не знаю ни среды, ни пятницы. А книг у меня нет, когда меня пограбили, то и книги у меня взяли» (Хождение за три моря ... ,1958: 83). В записках Василия Гагары самым ярким эмоциональным моментом являлось описание ситуации покаяния как «в той велицей церкве» ноги у него отнялись и стоять не мог, и продлилось это больше часа, пока он плакал, каялся перед Богом и призывал Его себе на помощь. «А греческие же попы и мнихи, на мя, многогрешного раба зря, восплакася, что ни над кем такова Божия послания не бывало» (Житие ..., 1891: 9).

Однажды Афанасий Никитин вспылил на «черных людей» из Бидара, которые - «злодеи», потому что здесь: «знахарство, воровство, ложь и зелье, которым морят господарей» (Хождение за три моря ... ,1958: 76). Скорее всего, за каждым из этих выводов стоит не одна увиденная и пережитая ситуация, но купец не впадает в детализацию, а делает общее заключение. Кроме того, фраза свидетельствует о явлениях, отвергаемых Афанасием в пользу противоположных по характеру христианских ценностей: не убий, не укради, не лги.

Афанасий Никитин был одним из первых русских купцов-землепроходцев (XV в.), опередив будущих коллег на два столетия. C XVII в. прослеживается значимая роль отечественных купцов-землепроходцев в деле открытия и освоения новых земель. Например, первооткрывателем Камчатки считается холмогорец Федот Алексеевич Попов - торговый человек, который вместе с Семеном Дежневым в 1648 г. отправился в экспедицию по поиску моржовой кости. Семен Дежнев вспоминал, что сначала Федота «чукочьи

преступникам в Персии. Если преступник успел убежать и скрыться за воротами мечети в Ардебиле, его не могли тронуть, здесь действовал закон неприкосновенности. Котов сравнивал это место с русскими монастырями: «Их кормят, как в русских монастырях, из одного котла за счет монастырских доходов. Бывает, что этих виновных людей выпускают из монастыря, дают их на выкуп тем, кому они нужны, но с последних берут клятву, что они не сделают вреда виновным и не будут их казнить» (там же: 73). 
люди» ранили в драке, а потом их «на море разнесло без вести» (Берг, 2011: 49). Через 7 лет Семен вновь отправился в экспедицию и узнал, что «Федот и служивый человек Герасим померли цингою» (там же: 50). Л. С. Берг считал, что потерпев крушение, Федот с оставшимися членами команды дошел до Камчатки, и через много лет во время похода Атласова (1697-1699) удалось выяснить у местных жителей, что при впадении реки Федотовки в Камчатку жил некто Федотов ${ }^{1}$. Г. Миллер во время Первой Камчатской экспедиции (1728-1729) видел остатки двух русских зимовий. Л. С. Берг восхищался отвагой мореплавателей, считая что такое плавание и в XIX-XX вв. было сложным и опасным, а путешественники XVII в. плыли по Ледовитому морю в кочах - одномачтовых судах, на которых можно было ходить только по ветру. О Федоте Алексееве писал и М. В. Ломоносов, отмечая смелость и отвагу землепроходца (Ломоносов, 2011). Михаил Васильевич писал еще об одном «промышленном человеке Иване Велигине», который в море по льду ездил и нашел новую землю, но из-за сильного ветра и тумана не смог определить остров это или материк, однако заметил там старые юрты, каменные горы и звериные следы (там же: 229).

Известный мореплаватель С. П. Крашенинников, рассказывая о деятельности купечества на Камчатке, говорил о тех людях, которые с момента покорения Камчатки приезжали с целью осуществления служебных обязанностей и получения сиюминутной прибыли, но Крашенинников говорит, что «за купцов их почитать нельзя», так как они «не пеклись о купечестве» (Крашенинников, 2011: 327). Можно понимать слова Крашенинникова так: настоящие купцы были нацелены не на одномоментное получение личной прибыли, а на основательное обустройство дела, не только с личной пользой, но с пользой для Отечества.

Непрофессиональные «купцы» распродавали сразу все, что имели, «льстясь на дороговизну, а сами остаются ни с чем, уповая на скорый выезд», но не имея возможно сразу уехать, вынуждены впоследствии покупать необходимые им товары за двойную цену (Крашенинников, 2011: 328). Был и другой вариант непрофессионального подхода к делу торговли: новоявленные купцы, получив барыш, «вдавшись роскоши», не смели вернуться к своим хозяевам, поселялись на новых землях и впоследствии разорялись, так как «мягкая рухлядь чем более лежит, тем более оцветает, а следовательно теряет свою доброту и цену» (там же).

Профессиональные купцы действовали иначе: они основывали фактории, вовремя вывозили товары на материк, платили в казну 10\% пошлины

${ }^{1}$ Возможно, потомок Федота Алексеева; а река, в свою очередь, была, вероятно, названа в честь русского купца-первооткрывателя. 
и попутно занимались исследованием новых земель, отправляя сведения об этом в столицу. Они были нацелены не только на получение личной прибыли, но и на государственную пользу. Например, в 1766 г. императрица Екатерина II велела вернуть купцу Толстых 1/10 прибыли, т. е. не взяла в казну процент за добытый товар в награду за большой вклад купца в дело исследования новых земель (Берх, 1823: 56). Кроме того, Андриан Толстых установил добрые и деловые отношения с аборигенами, «завоевал благорасположение всех островитян, собрав при том значительный груз» ${ }^{1}$ (возникает аналогия с образом Афанасия Никитина и индусами). Кроме того, он не раз помогал своим коллегам по бизнесу. В 1761 г. принял на борт потерпевших кораблекрушение морехода Башмакова с командой. На обратной дороге его собственное судно потерпело крушение, но Толстых спас людей, груз и, кроме того, доставил в столицу описание шести новых открытых островов. Купец не останавливался на достигнутом, ставя перед собой новые исследовательские задачи. Он искал Дегамову землю, которую пытался найти Беринг, но судно было разбито о скалу, из 63 человек команды, выжили только трое, сам купец Андриан Толстых погиб.

Купцы выступали в роли активных исследователей, в том числе картографов. Так, казак Пономарев доставил Правительству обстоятельную карту Алеутских островов, а в рапорте написал, что карта составлена вместе с тотемским купцом Шишкиным (Берх, 1923). В 1748 г. на острове Кадьяк обосновался рыльский купец Г. И. Шелехов, построив укрепления, вернувшись через 3 года в Иркутск, он представил отчет о путешествии и карты исследованных земель (Берг, 2011).

Способность эффективно взаимодействовать с партнерами по бизнесу ярко иллюстрируется в деятельности купцов-землепроходцев. Некоторые купцы, осваивающие новые земли, объединялись друг с другом, с военными людьми, с капитанами-мореходами. Так московский купец Андрей Серебренников в 1743 г. совместно с сержантом Басовым построили маленькое судно и дошли до Берингова острова. Экспедиция носила разведывательный характер. Через два года, в 1745 г. к ним присоединился иркутский купец Никифор Трапезников и за время экспедиции компаньоны собрали 1600 морских бобров, 2000 котиков и столько же голубых песцов. Возвратившись, «они показали соотечественникам новую дорогу к обширной, богатой промышленности» и отправили отчет о находках самородной меди, незнакомой руды и «новокурьезной рыбки» (Берх, 1823: 4). Все образцы

\footnotetext{
${ }^{1}$ Не у всех землепроходцев складывались мирные отношения с местными жителями. Известна осада алеутами зимовья Дружинина, в битве выжили не многие русские поселенцы (Берх, 1823: 60).
} 
были отправлены для изучения. В. Н. Берх свидетельствует о том, что купец Серебренников открыл новых островов «довольно значительное число» (Берх, 1823: 29). Купец Никифор Трапезников на своем судне «Борис и Глеб» в 1749 г. вновь отправился в экспедицию, пробыл на Алеутских островах уже четыре зимы, привез товар, оцененный в 105730 рублей, а также открыл большой остров Атху (Берг, 2011: 11). Иркутский купец Лебедев-Ласточкин пробыл на островах более 8 лет, привез богатый груз и открыл острова св. Петра и Павла (Берх, 1823: 102).

Часто в землепроходческие сообщества объединялись купцы разных регионов, что свидетельствует о тесном контакте купцов в рамках профессионального сообщества не только своей губернии, но и всей страны. Так, судно «Иоанн» принадлежало одновременно тотемскому купцу Федору Холодилову, иркутским купцам Трапезникову и Балину, а также ярославскому купцу Жукову, а в экспедицию в 1746 г. отправился купец Андриан Толстых. В 1759 г. в совместную экспедицию отправились шуйский купец Постников, тульский купец Красильников и вологодские купцы Кульковы (Берг, 2011).

В первой половине XIX в. историк флота и географических открытий, полковник Василий Николаевич Берх писал о русских купцах-землепроходцах: «Признаюсь, что всю статью сию писал я с особенным удовольствием; ибо она изображает решительную предприимчивость почтенных соотечественников наших, которые заменяли недостаток познаний, отважностью и непоколебимою твердостью духа» (Берх, 1823: 130). Военный историк, отмечая волевые качества купцов и «их истинно геройское терпение» (там же: 22). Сталкивались с огромным количеством трудностей: суда разрушались о рифы, зачастую приходилось строить новые из обломков старых; болезни, голод, холод; островитяне не всегда дружелюбно встречали, но как и в прежние времена, купцы не отступали.

\section{Купцы и государственная служба}

Реконструированный образ русского купечества позволил предположить, что они могли являться эффективными государственными служащими. Так, Трифон Коробейников после первого своего путешествия был пожалован чином дьяка ${ }^{1}$. Но статистика показывает, что среди дьяков было очень мало выходцев из купеческого сословия. Из 62 дьяков Ивана III - трое, из 92 дьяков Василия III - шестеро, из 300 дьяков Ивана Грозного - трое, остальные - из состава традиционного, служилого, боярско-дворянского сословия. А. Ю. Савосичев, проанализировав данную статистику и изучив деятельность купцов-дьяков из семей Таракановых и Сырковых, констати-

\footnotetext{
${ }^{1}$ Дьяк — на Руси в XIV-XVII вв. должностное лицо в государственном учреждении.
} 
рует, что купечество было замкнутым сословием, неохотно переходящим к каким-либо другим занятиям, но, даже перейдя на приказную работу (официальную государственную службу), они продолжали заниматься привычной для них деятельностью, связанной с торговлей и финансами (Савосичев, 2009).

В конце XVI в. еще более возрастает роль купечества в государственно-политической жизни страны. Купцы Гостиной и Суконной сотен привлекаются к обязательному несению службы в финансовых органах управления государством, в качестве таможенных и кабацких голов, оценщиков и продавцов правительственных товаров (Павлов, 2009). В XIX в. органы городского самоуправления практически полностью были отданы в руки купечества: должность городского головы традиционно занимали купцы и в составе городской думы в основном были представители купечества и мещанства. Таким образом, в ситуациях требующих реальной, «черновой» работы в вопросах, касающихся финансово-экономической сферы жизни государства, к купечеству обращались за помощью, а порой и обязывали безвозмездно осуществлять государственно-полезную работу. В вопросах, касающихся раздачи должностей, привилегий, чинов купечество стояло далеко не на первом месте, о нем часто «забывали».

А. В. Павлов, изучив историю жизни выдающейся личности первой трети XVII в. - Михаила Ивановича Смывалова, - выходца из смоленского купечества, констатирует: «В условиях безраздельного господства при московском дворе представителей боярской служилой и придворной аристократии худородным выходцам из “торговых мужиков" была уготована лишь карьера временщиков» (Павлов, 2009: 126). Ничего не изменилось в ситуации XIX - н. XX вв. Л. Н. и О. Г. Жуковы, изучив историю жизни и деятельности Василия Васильевича Кокорева, знаменитого купца XIX в., пишут: “"Кандидат в министры финансов" - это прозвище дали Кокореву после кончины, вспомнив все его грандиозные деяния и предложения мер по предотвращению будущих “великих потрясений”. И дали, пожалуй, все же в шутку, но грустную, потому как в России того времени купец, будь он хоть финансовым гением, никаких высоких государственных постов занимать не мог» (Жукова Л., Жукова О., 2017: 42).

Наши ранние исследования подтверждают существование противоречивых отношений между купечеством и дворянской аристократией на протяжении всего пути становления купечества как социальной группы. У купечества с одной стороны, существовало стремление уравняться в правах с дворянством; с другой - нежелание выходить за рамки своего сословия в силу несовпадения купеческой системы ценностей с дворянской. У дворянства с 
одной стороны, отношение к купечеству колебалось от снисходительного до откровенно презрительного; с другой - существовала необходимость считаться с ним как с возможным кредитором (Кольцова, Федоркова, 2018).

Таким образом возникает вывод о том, что купцы, начиная с древних времен служили Отечеству и государству в основном на общественных началах, не состоя официально на государственной службе, они осуществляли дипломатические, разведывательные, научно-просветительские, исследовательские функции. Независимо от мотива, сами они не хотели выходить за пределы своего сословия, или им не давали этого сделать, можно констатировать существование устойчивой жизненной позиции купечества служение Отечеству - основанной на христианском смирении, любви и служении. Им не давали чинов, редко приглашали на высокие должности, дающие привилегии, а они по мере своих возможностей и сил продолжали параллельно с основной торгово-промышленной деятельностью, трудиться на благо Отечества. Находясь в одной из критических ситуаций в Индии, задумавшись о возвращении на родину, Афанасий Никитин призывал на помощь Господа и говорил о Руси: «Русская земля да будет Богом хранима! Боже сохрани! Боже сохрани! На этом свете нет страны подобной ей, хотя вельможи (бояре) Русской земли несправедливы (не добры). Да станет Русская земля благоустроенной, и да будет на ней справедливость» (Хождение за три моря ... , 1958: 85).

\section{Заключение}

О купцах-международниках средневековой Руси мы можем говорить как о людях весьма образованных: они не только владели грамотой, но и иностранными языками; вели не только свои финансовые записи, но и являлись авторами художественных произведений; не только осуществляли торговые операции, но и выполняли роль дипломатов, просветителей, проводников, фельдъегерей и т. д.

Анализ деятельности русских купцов позволил сделать вывод о доминировании в ней мотива служения Отечеству, что проявлялось с княжеского периода и до конца существования данного сословия (до 1917 г.). Общественное служение купечества выражалось в осуществлении ими следующих функций: дипломатической (официального и неофициального характера), информационной (информаторы летописцев и субъекты формирования общественного мнения по разным вопросам), духовно-просветительской (паломнические записки и материалы к истории христианской церкви); культурно-просветительской (как писатели, оставившие путевые записки по истории, этнографии, географии разных стран), научно-просветительской (причастность к открытию и исследованию новых земель).

Поездки купцов за границу могли являться как отражением внутрен- 
ней мотивации - собственной инициативы купечества, так и следствием внешней мотивации - официального государственного поручения. Вместе с тем, даже в описании поездок, вызванных частной инициативной, просматривается доминирование мотива служения на пользу Отечества.

Паломнический характер путевых заметок, участие в благотворительных экспедициях на Восток, эмоциональные реакции на переживания религиозных чувств позволяют сделать вывод о христианской вере как основе системы ценностей русского купечества. Александрийский патриарх писал царю Михаилу Федоровичу о купце Василии Гагаре: «Господин Василий, оказавшийся здесь вполне добрым христианином, преданным церкви, благочестивым и богобоязненным, таким именно, что все здешние христиане, и греки, и арабы, воздали славу Богу, говоря: «справедливо Бог даровал московитянам царство, ибо они столь благочестивые и богобоязненные христиане» (Второе хождение ..., 1887: 88).

При написании путевых заметок выявлена ориентация на общественную пользу, а не на описание личностно-значимых событий и собственных поступков благотворительного характера как демонстрация отсутствия эгоцентризма и скромность у купечества. Необходимо отметить и высокий уровень образованности русских купцов-международников: грамотность, хорошее знание Священного Писания и Священной истории (свободное цитирование и использование знаний при подготовке заметок); знание иностранных языков (как минимум это известно об Афанасии Никитине и Трифоне Коробейникове).

Среди личностных свойства купцов, реконструированных на основе разных источников (купеческих путевых заметок; документов и исследований, относящихся к их деятельности) можно назвать следующие: волевые качества (готовность к риску, смелость, решительность, целеустремленность, выносливость, высокий уровень самообладания и самоконтроля, способность к преодолению сложных ситуаций); когнитивные качества (высокая познавательная активность, любознательность, наблюдательность, критичность и самостоятельность мышления, смекалка); организаторские способности (способность действовать в сложной ситуации; способность принимать на себя ответственность за дело и людей, предприимчивость); при общей сдержанности в проявлении эмоций - глубина религиозных переживаний, смирение (служение Отечеству в условиях существования тенденции - не допуска их во властные структуры), милосердие, социально-психологическая компетентность (компетентность в общении, эффективность взаимодействия как с партнерами по бизнесу: единоверцами и иноверцами, так и с лицами неторговых сословий разных стран и разных этнических групп). 


\section{СПИСОК ЛИТЕРАТУРЫ}

Берг, Л. С. (2011) История великих русских географических открытий. М. : Эксмо. 640 с.

Берх, В. Н. (1823) Хронологическая история открытия Алеутских островов или подвиги Российского Купечества с присовокуплением исторического известия о меховой торговле. СПб. : Типография Н. Греча. 169 с.

Борисов, Н. С. (1995) Иван Калита. М. : Молодая гвардия. 302 с.

Второе хождение Трифона Коробейникова с предисловием С. О. Долгова (1887). М. : В Университетской типографии (М. Каткова) на Страстном бульваре. 18 с.

Данилов, В. В. (1962) О жанровых особенностях древнерусских «хождений» // Труды отдела древнерусской литературы. М. ; Л. : Изд-во АН СССР. Т. 18.607 с. С. $21-37$.

Житие и хождение в Иерусалим и Египет казанца Василия Яковлева Гагары 1634-1637 гг. (1891) / Православный Палестинский сборник. Т. XI, вып. 3. Издание Императорского Православного Палестинского Общества / под ред. С.О. Долгова. СПб. : типография В.Киршбаума. 104 с.

Жукова, Л.Н., Жукова, О.Г. (2017) Русское купечество. Гении Дела и творцы истории. М. : Вече. 352 с.

Карпов, А. Ю. (2004) Владимир Святой. 2-е изд. испр и доп. М.: Молодая гвардия. 454c.

Кириллов, И. А. (1996) Третий Рим. М. : Третий Рим. 112 с.

Кольцова, В. А., Федоркова, И .Р. (2018) Становление отечественного купечества в процессе его взаимодействия с разными социальными группами российского общества // Человек и Мир. Т. 2, № 3(5). С. 9-32.

Крашенинников, С. П. (2011) Выдержки из «Описания Камчатки». 0 покорении Камчатки, о бывших в разные времена бунтах и изменах и о нынешнем состоянии российских острогов // Берг Л. С. История великих русских географических открытий. М. : Эксмо. С. 299-339.

Лихачев, Д. С. (2008) Повести русских послов как памятники литературы // Путешествия русских послов XVI-XVII вв. Статейные списки. Репр. воспр. изд. 1954 года. СПб. : Наука. 491 с.

Ломоносов, М. В. (2011) Краткое описание разных путешествий по северным морям и показание возможного проходу Сибирским океаном в Восточную Индию // Берг Л. С. История великих русских географических открытий. М. : Эксмо. С. 213-251.

Лопарев, Хр. (1889) Предисловие. C.I-XXXVII // Православный Палестинский сборник. T. IX, выпуск третий (выпуск 27). Издание православного Палестинского общества. СПб. : Типография Киршбаума, в д. М-ва Финансов на Дворц.площ. 127 с. 
Лощиц, Ю. (2010) Дмитрий Донской, князь благоверный. М. : Молодая гвардия. 326 с.

Морозова, Л. Е. (2017) Великие и неизвестные женщины Древней Руси. М. : Академический проект. 391 с.

Осипов, А. М. (1956) Афанасий Никитин и его время. 2-е изд., испр. и доп. М. : Учпедгиз. 216 с.

Отчет дьяка Трифона Коробейникова в розданной царской милостыни (1889) / Православный Палестинский сборник. T. IX, выпуск третий (выпуск 27). Издание православного Палестинского общества. СПб. : Типография Киршбаума, в д. М-ва Финансов на Дворц.площ. 127 с. С. 84-103.

Павлов, А. В. (2009) Гость и дьяк Михаил Смывалов: штрихи к биографии // Торговля, купечество и таможенное дело в России в XVI-XIX вв. / сост. А. И. Раздорский. Курск : Курский государственный университет. 375 c. С. $123-128$.

Перхавко, В. Б. (2012) Средневековое русское купечество. М. : Кучково поле. 623 с.

Петрушевский, И. П. (1958) Комментарий исторический и географический // Хождение за три моря Афанасия Никитина 1466-1472. 2-е изд., дополненное и переработанное. М. ; Л: Издательство Академии наук СССР. C. 187-251.

Послание царя Ивана Васильевича к Александрийскому патриарху Иоакиму с купцом Василием Позняковым и Хождение купца Познякова в Иерусалим и по иным святым местам 1558 года с предисловием И. Е. Забелина (1884). М. : Университетская типография (М. Катков). 44 с.

Поучение или Духовная Великого Владимира Всеволодовича Мономаха детям своим (1996). М. : Фонд им. Д. И. Сытина. 240 с.

Преображенский, А. А., Перхавко, В. Б. (1997) Купечество Руси. IX-XVII вв. Екатеринбург : Демидовский институт. 304 с.

Путешествие московских купцов Трифона Коробейникова и Юрия Грекова (1994) // Путешествия в Святую Землю. Записки русских паломников и путешественников XII-XX вв. М. : Лепта. 256 с. С. 50-77.

Путешествие московских купцов Трифона Коробейникова и Юрия Грекова (1999). М. : Международный фонд единства православных народов. $30 \mathrm{c}$.

Решетова, А. А. (2007) Паломник, посланник или негоциант? (исследование историко-литературной основы «Хождения» Василия Гагары) // Вестник Рязанского государственного университета им. С. А. Есенина. № 4/17. С. 134-148.

Савосичев, А. Ю. (2009) Приказная бюрократия и купечество в России XVI в. // Торговля, купечество и таможенное дело в России в XVI-XIX вв. / 
сост. А. И. Раздорский. Курск : Курский государственный университет. 375 с. C. 30-34.

Соловьев, С. М. (2007) История России с древнейших времен. М. : Эксмо. $1024 \mathrm{c}$.

Сандыбаева, Н. А. (1981) Лексика восточного происхождения в «Хождении за три моря» Афанасия Никитина : автореф. дисс. ... канд. фил. н. Л. 11 с.

Сказания и повести о Куликовской битве (1982). Л. : Наука. 441 с.

Федоркова, И. Р. (2017) Соль - универсальные товарные деньги прошлого // Банкноты стран мира. № 5, май. С. 32-33.

Федоркова, И. Р. (2018) Зарождение отечественного купечества: исторические условия, психологические и социально-психологические характеристики, особенности деятельности // Человек и Мир. Т. 2. № 2. С. 128-154.

«Хожение» игумена Даниила в Святую Землю в начале XII века (2007) / отв. ред. Г. М. Прохоров. СПб. : «Издательство Олега Абышко». 416 с.

Хожение гостя Василия в Малую Азию, Египет и Палестину (1984) // Книга хожений. Записки русских путешественников XI-XV вв. / сост., подгот. текста, пер., вступ. статья и коммент. Н. И. Прокофьева. М. : «Советская Россия». 448 с.

Хождение купца Трифона Коробейникова по Святым местам Востока(1889) / Православный Палестинский сборник. T. IX, выпуск третий (выпуск 27). Издание православного Палестинского общества (1889). СПб. : Типография Киршбаума, в д. М-ва Финансов на Дворц.площ. 127 с. С. 1-71.

Хождение за три моря Афанасия Никитина 1466-1472 (1958). 2-е изд., дополненное и переработанное. М.-Л. : Издательство Академии наук СССР. 302 c.

Хождение купца Федота Котова в Персию (1958). М. : Издательство Восточной литературы. $111 \mathrm{c}$.

Шишов, А. В. (2006) Иван Калита. Собиратель русских земель. М. : Вече. 448 c.

Дата поступления: 25.09.2019 г.

Федоркова Ирина Рудольфовна - кандидат психологических наук, доцент кафедры общей психологии и истории психологии Московского гуманитарного университета. Адрес: 111395, Россия, г. Москва, ул. Юности, д. 5. Тел.: +7 (499) 374-67-20. Эл. адрес: ira_kislova@mail.ru

Fedorkova Irina Rudolfovna, Candidate of Psychology, Associate Professor, Department of General Psychology and History of Psychology, Moscow University for the Humanities. Postal address: 5, Yunosti St., Moscow, Russian Federation, 111395. Tel.: +7 (499) 374-67-20. E-mail: ira_kislova@mail.ru 


\section{Для цитирования:}

Федоркова И. Р. Образ русского купца: стереотипы и реальность [Электронный ресурс] // Научные труды Московского гуманитарного университета. 2019. № 5. URL: http://journals.mosgu.ru/trudy/article/view/1055 (дата обращения: дд.мм.гг.). DOI: 10.17805/trudy.2019.5.6 